
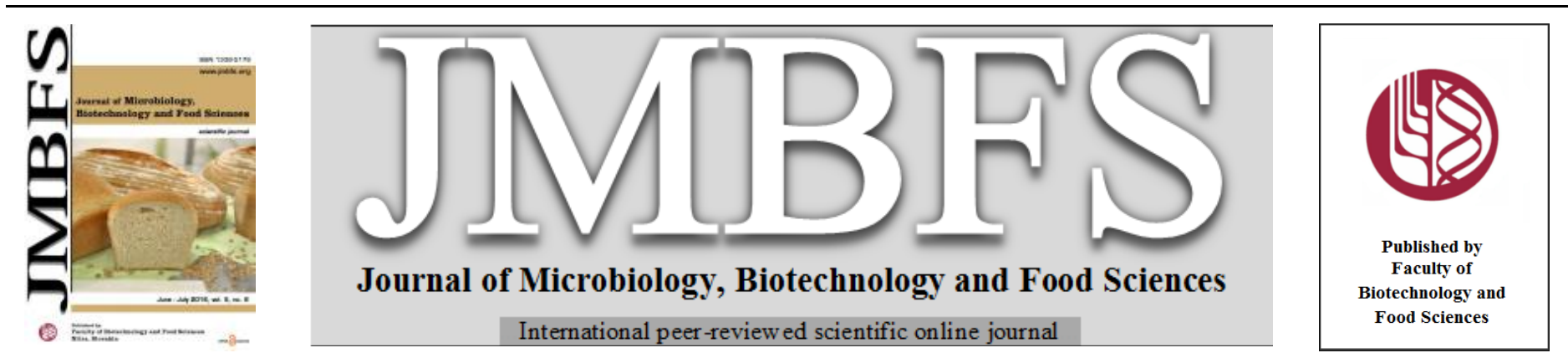

\title{
MICROBIOTA OF PINUS POLLEN AS ADJUVANT FACTOR OF ALLERGY
}

\section{Tetiana Shevtsova ${ }^{* 1}$, Miroslava Kačániová ${ }^{2}$,Jana Petrová2 , Ján Brindza ${ }^{3}$, Kateryna Garkava ${ }^{1}$}

Address(es): Mgr. Tetiana Shevtsova

${ }^{1}$ National Aviation University, Educational and Research Institute of Environmental Security, Department of Biotechnology, Kosmonavta Komarova ave., 1, 03058 Kyiv, Ukraine.

${ }^{2}$ Slovak University of Agriculture in Nitra, Faculty of Biotechnology and Food Sciences, Department of Microbiology, Tr. A. Hlinku 2, 94976 Nitra, Slovak Republic. ${ }^{3}$ Slovak University of Agriculture in Nitra, Institute of Biodiversity Conservation and Biosafety, Tr. A. Hlinku 2, 94976 Nitra, Slovak Republic.

*Corresponding author: shevtsovat@ukr.net

doi: 10.15414/jmbfs.2016.5.6.627-632

\section{ARTICLE INFO}

Received 3. 3. 2016

Revised 6. 4. 2016

Accepted 3. 5. 2016

Published 1. 6. 2016

Regular article

open 2 ACcess

\begin{abstract}
Bacteria, their endotoxin and mold found on pollen can be a reason of respiratory symptoms in sensitized individuals. This question concerns an anemophilous pollen more acute. In this work quantitative by dilution plating method and qualitative microbial analysis by MALDI-TOF MS Biotyper of pollen and other plants organs of Pinus sylvestris L., P. nigra Arnold, P. mugo Turra, P. armandii Franch., $P$. wallichiana A.B. Jacks from Nitra, Slovakia are performed which shows quantitative and species differences in mesophilic aerobic (0.00-6.27 log cfu/g) and anaerobic bacteria (0.00-3.70 log cfu/g), enterococci ( $0.00 \mathrm{log} \mathrm{cfu} / \mathrm{g})$, coliform bacteria $(0.00-5.29 \mathrm{log}$ $\mathrm{cfu} / \mathrm{g})$, lactobacilli (0.00-4.20 log cfu/g), microscopic fungi and yeasts (2.60-5.29 log cfu/g) content. Representatives of Pseudomonas (14), Bacillus (2), Acinetobacter (1), Arthrobacter (1), Pantoea (1), Klebsiella (1), Penicillium (6), Aspergillus (4), Cladosporium (1), Debaryomyces (1) genera were revealed on pine trees. The allergenic potential of the identified association of microorganisms on pollen has been evaluated based on published data. The results may be useful for aerobiologists, allergists and microbiologists, at least at the local level.
\end{abstract}

\section{INTRODUCTION}

Pinus pollen has natural properties to be allergenic: 1. it's anemophilous; 2 . released in large quantities; 3. the genus is widespread in nature (Noks, 1985; Behrendt and Becker, 2001; D'Amato et al., 2007; Maňka et al., 2013; Turos et al., 2013). At the same time, a Pinus pollen grain, for example, Pinus sylvestris $\mathrm{L}$. is heavier $(30.08 \mathrm{m \mu g})$ in comparison with a pollen grain of Betula verrucosa Ehrh. $(9.48 \mathrm{m \mu g})$ - known potent allergen. They also differ slightly both settling velocity of grains in still air: for $P$. sylvestris $\mathrm{L}$. is $3.69 \mathrm{~cm} / \mathrm{sec}$, for $B$. verrucosa Ehrh. $-2.94 \mathrm{~cm} / \mathrm{sec}$ and the probable range drift of pollen by wind $-1700-1775$ and $600 \mathrm{~km}$, respectively (Dyakowska and Zurzycki, 1959). It is known more widely about the beneficial properties of pine pollen (Lee et al., 2009; Solntseva and Glazunova, 2010). Pine pollen has long been considered a non-allergenic pollen (Gastaminza et al., 2009; Vinhas et al., 2011). The main reasons of this are the large size of a grain, its low levels of proteins and the presence of a waxy hydrophobic layer that averts protein release. Thus, the length of the polar axis of the $P$. sylvestris L. pollen grain is $67.4(60-74) \mu \mathrm{m}, P$. nigra $-75.5(67-87) \mu \mathrm{m}$. For comparison, the size of Betula pendula pollen grain is only $22.6(21-25) \mu \mathrm{m}$ (polleninfo). As Pridal (2003) determined the amount of proteins in the pollen of Betula is $23.02 \%$, in Pinus pollen - $14.14 \%$ (Nôžková et al., 2014). Özler et al. (2009) defined pollen of Pinus nigra subsp. nigra var. caramanica as important allergenic tree pollen because of content of amino acids and total protein. Gastaminza et al. (2009) detected high degree of cross reactivity among the pollen of the distinctive pine species. Cases of allergic sensitization by pine pollen are known and enough spread (Green et al., 2003; Gastaminza et al., 2009).

The genus Pinus includes 116 species. This genus is subdivided into subgenus Strobus with 43 species and subgenus Pinus with 73 species (Maňka et al., 2013). Pinus pollen is predominant in the atmosphere of most environments: from the Arctic Circle to Guatemala, the West Indies, North Africa and Malayan Archipelago (Green et al., 2003; Maňka et al., 2013). Slovakia, as a mountainous and forested country (40.6\% forest cover) in central Europe, has a large variety of vegetation zones, forest types, and a rich variety of forest tree species. Pinus sylvestris L. is one of the most important tree species (Oszlányi, 1997). Pines are frequently planted in city parks or near streets (Ivanová and Bernadovičová, 2010; Dušička et al., 2013). Plant wealth, closeness to living environments and regional geography are additional factors that can prompt to local allergic sensitization by pine pollen (Shah and Grammer, 2012).

Gram-negative and Gram-positive bacteria, mould are the source of allergens. They were revealed on the surface of the pollen grains of anemophilous plants as well as endotoxin (Śpiewak et al., 1996; Heydenreich et al., 2011; Mittag et al., 2013). These microorganisms are attached to the pollen exine or located within the pollen cells likely before the opening of the catkins. On the other hand they may be airborne contaminants that alight on the pollen during collection and handling (Madmony et al., 2005). Airborne bacteria are more likely use pollen grain as a transport or source of nutrients (González et al., 2005; Madmony $e t$ al., 2005; Després et al., 2011). Such pollen-associated bacteria have a privilege: ability to thrive within plant tissues gives them, in turn, with several advantages, e.g., an environment with little competition, protection from environmental stresses and a reliable food source (Madmony et al., 2005). Heydenreich $\boldsymbol{e t}$ al. (2011) showed that Gram-positive and Gram-negative bacteria on the surface of grass pollen grains may serve as adjuvants by augmenting dendritic cells maturation and inflammatory Th1, Th2 and Th17 responses helping to initiate allergic immune responses.

Based on the aforesaid the aim of this study is to analyze the surface of Pinus pollen grains on the presence of microorganisms, identify them and conclude about allergenic potential of Pinus pollen known as pollen with low allergenicity.

\section{MATERIALS AND METHODS}

\section{Selected Pinus species}

Five Pinus species were selected for microbiological analysis. They are: Scots pine $(P$. sylvestris L. (PS)), Austrian pine also called European black pine $(P$. nigra Arnold (PN)), Dwarf pine ( $P$. mugo Turra (PM)), Chinese white pine $(P$. armandii Franch. (PA)), Blue pine or Himalayan pine ( $P$. wallichiana A.B. Jacks (PW)). P. sylvestris, P. nigra, P. mugo belong to the subgenus Pinus, P. armandii and $P$. wallichiana - to the subgenus Strobus (Maňka et al., 2013).

Scots pine and dwarf pine represent the two principal species of pines indigenous to Slovakia. They distribute mainly allopatric in the country (Kormut'ák et al., 2013). P. sylvestris L. has been chosen as the main object of this study as it is the widespread species. 
All trees are growing in the same natural conditions at the Botanical garden of the Slovak Agricultural University in Nitra.

\section{Plant and pollen materials description}

Unopened male cones were collected before they were ready to shed pollen aseptically in April-May 2015. Then they were dried at room temperature overnight. Pollen was collected the next day, keeping sterile conditions. Samples were placed in a cooler and conserved for a few days until analysis at $+4^{\circ} \mathrm{C}$ Since some Pinus species flowered with a difference of one month, the microbiological analysis of pollen samples was carried out when the plant material was collected.

Samples of the other organs of Pinus sylvestris L. trees were collected for a more detailed analysis. They are: male cones before, during and after flowering, young and mature female cones, needles. Also male cones during and after flowering were prepared for the other Pinus species. Altogether thirteen pine samples were collected.

All the trees are without visible damage.

\section{Air samples}

Air samples around the trees were studied for comparison the qualitative composition of the microbiota of trees and air. Air is not a medium in which microorganisms can develop, but has a carrier particulate matter, dust and droplet which can be weighed down with microbes (Latha and Mohan, 2013). "Kochtype" sedimentation method was used for sampling the air (Tóth et al., 2013). Open Petri dishes with meat peptone agar medium (Imuna, Slovak Republic) and malt extract agar base (Biomark Laboratories, India) were placed under the studied tree's crown and exposed for 10 and 15 minutes. Air sampling was performed three times on different days. Altogether fourteen air samples were investigated.

\section{Quantitative microbial analysis}

One gram of each sample of pollen were diluted in $99 \mathrm{~mL}$ of sterile saline solution and mixed for $30 \mathrm{~min}$ by vigorous shaking in Rotamax 120 Orbital shaker (Heidolph, Germany) $(175 \mathrm{rpm})$ at room temperature. Ten-fold serial dilutions of suspension were made up to $10^{-3}$. The serial dilutions were inoculated on appropriate nutrient media. In whole every sample was cultivated on Petri dishes quadruplicate on six kinds of nutrient media. The formed colonies on the plates were counted and expressed as log colony forming units/g (log cfu/g).

Total mesophilic aerobic and anaerobic microbiota was determined by spreading $1 \mathrm{~mL}$ from the appropriate dilution into sterile Petri dishes to which meat peptone agar (Imuna, Slovak Republic) was poured. Plates were incubated aerobically at $25^{\circ} \mathrm{C}$ and counted after $48-72 \mathrm{~h}$.

Total Enterococcus was determined in the same way but only Slanetz-Bartley medium was used (HiMedia, India). Plates were incubated at $37^{\circ} \mathrm{C}$ for $48 \mathrm{~h}$.

Total coliforms: A $1 \mathrm{~mL}$ aliquot of the appropriate dilution were transferred into Petri plates and poured with violet red bile with lactose agar (Pronadisa, Spain). Plates were incubated at $37^{\circ} \mathrm{C}$ and colonies were counted after $24 \mathrm{~h}$.

Lactobacilli were determined by spreading of $1 \mathrm{~mL}$ from the appropriate dilutions on MRS Agar Modified (HiMedia, India) and incubated at $37^{\circ} \mathrm{C}$ for 48 $72 \mathrm{~h}$.

Total microscopic fungi and yeasts were determined by spreading $0.1 \mathrm{~mL}$ from appropriate dilutions on Sabouraud medium (Biomark Laboratories, India). Plates were incubated at $28^{\circ} \mathrm{C}$ and counted after 7 days

\section{Qualitative microbial analysis}

Qualitative microbial analysis of plant materials was performed using MALDITOF Mass Spectrometry (Bruker Daltonics, Germany). MALDI-TOF MS is a rapid, reliable diagnostic tool for the identification of most microorganisms (Barberis et al. 2014). For identification, the Biotyper software compares the sample spectrum to its database of spectra generated using characterized isolates (DeMarco and Burnham 2014). After counting of the colonies best of them were selected for the identification. All isolates were pick out from the Petri dishes and transferred into $300 \mu \mathrm{L}$ of distilled water in Eppendorf tubes. Then $900 \mu \mathrm{L}$ of ethanol was added and the tubes were centrifuged for 2 minutes at 14,000 npm The supernatant was carefully pipetted off and discarded. The same spin was repeated on the pellet. All remaining ethanol was removed, and the pellet was allowed to dry. Ten microliters of $70 \%$ formic acid was mixed with the pellet by pipetting and vortexing. Then $10 \mu \mathrm{L}$ of acetonitrile was added. Tubes were centrifuged for 2 minutes at 14,000 npm and $1 \mu \mathrm{L}$ of the supernatant was applied to the MALDI target. Once dry, every spot was overlaid with $1 \mu \mathrm{L}$ of HCCA matrix and left to dry at room temperature before analysis. Spectra were generated and MALDI-TOF analyzed on the Microflex LT (Bruker Daltonics) instrument using Flex Control 3.4 software and Biotyper Realtime Classification 3.1 with BC specific software. Criteria for successful identification as proposed by the manufacturer were a confidence score of $\geq 2.0$ for species level and $\geq 1.7$ for genus level (DeMarco and Burnham, 2014).

\section{Statistical analysis}

Results were evaluated by standard techniques using MS Excel and Statistica 10. Mann-Whitney U-test was used for pairwise comparisons of the data.

\section{RESULTS}

Microbial content of Pinus trees samples is presented in Tables 1 and 2.

Table 1 Microbial enumeration of Pinus trees samples collected in Nitra, Slovak republic in $2015, \log \mathrm{cfu} / \mathrm{g}$

\begin{tabular}{|c|c|c|}
\hline \multirow[b]{2}{*}{ Plant part } & \multicolumn{2}{|c|}{ Group of microorganisms } \\
\hline & $\begin{array}{l}\text { Total mesophilic } \\
\text { aerobic counts }\end{array}$ & $\begin{array}{l}\text { Total mesophilic } \\
\text { anaerobic counts }\end{array}$ \\
\hline Male cones PS BF ${ }^{a}$ & 2.70 & 0.00 \\
\hline Male cones PS DF & 3.85 & 0.00 \\
\hline Male cones PN DF & 6.02 & 0.00 \\
\hline Male cones PM DF & 5.16 & 2.30 \\
\hline Male cones PS AF & 3.48 & 0.00 \\
\hline Needles PS AF & 3.00 & 0.00 \\
\hline Female cones mature PS DF & 0.00 & 3.00 \\
\hline Female cones young PS AF & 0.00 & 0.00 \\
\hline Pollen PS & 5.66 & 0.00 \\
\hline Pollen PN & 6.27 & 3.70 \\
\hline Pollen PM & 4.23 & 0.00 \\
\hline Pollen PA & 5.57 & 2.00 \\
\hline \multirow[t]{2}{*}{ Pollen PW } & 6.02 & 0.00 \\
\hline & $\begin{array}{c}\text { Enterococcus } \\
\text { counts }\end{array}$ & Total coliforms \\
\hline Male cones PS BF & 0.00 & 2.00 \\
\hline Male cones PS DF & 0.00 & 2.00 \\
\hline Male cones PN DF & 0.00 & 2.60 \\
\hline Male cones PM DF & 0.00 & 2.70 \\
\hline Male cones PS AF & 0.00 & 2.00 \\
\hline Needles PS AF & 0.00 & 0.00 \\
\hline Female cones mature PS DF & 0.00 & 0.00 \\
\hline Female cones young PS AF & 0.00 & 0.00 \\
\hline Pollen PS & 0.00 & 0.00 \\
\hline Pollen PN & 0.00 & 5.29 \\
\hline Pollen PM & 0.00 & 5.17 \\
\hline Pollen PA & 0.00 & 3.48 \\
\hline \multirow[t]{2}{*}{ Pollen PW } & 0.00 & 5.01 \\
\hline & $\begin{array}{c}\text { Total lactobacilli } \\
\text { counts }\end{array}$ & $\begin{array}{l}\text { Microscopic fungi } \\
\text { and yeast }\end{array}$ \\
\hline Male cones PS BF & 4.08 & 4.54 \\
\hline Male cones PS DF & 3.30 & 4.63 \\
\hline Male cones PN DF & 0.00 & 4.63 \\
\hline Male cones PM DF & 3.60 & 4.99 \\
\hline Male cones PS AF & 3.48 & 4.18 \\
\hline Needles PS AF & 3.30 & 2.60 \\
\hline Female cones mature PS DF & 3.85 & 3.95 \\
\hline Female cones young PS AF & 4.20 & 3.00 \\
\hline Pollen PS & 3.90 & 4.32 \\
\hline Pollen PN & 0.00 & 3.69 \\
\hline Pollen PM & 3.00 & 4.79 \\
\hline Pollen PA & 0.00 & 5.03 \\
\hline Pollen PW & 3.48 & 5.29 \\
\hline
\end{tabular}

As can be seen from Table 1 the total content of mesophilic aerobic bacteria of the investigated samples is 0.00 (young and mature female cones of $P$. sylvestris) - 6.27 (pollen of $P$. nigra) log cfu/g. A higher level of the presence of aerobic bacteria on pollen and male cones compared with female cones and needles clearly expressed. Within this group of microorganisms Pseudomonas asplenii, $P$. chlororaphis, $P$. corrugate, $P$. koreensis, $P$. orientalis, $P$. tolaasii, $P$. rhodesiae, $P$. fluorescens, $P$. libanensis, $P$. veronii, $P$. extremorientalis, $P$. trivialis, $P$. synxantha, $P$. grimontii, Bacillus flexus, $B$. licheniformis, Acinetobacter lwoffii, Arthrobacter sp. were identified using MALDI-TOF (see Table 2). All these bacteria were determined only on pollen grains.

The level of contamination by mesophilic anaerobic bacteria in comparison with the aerobic bacteria is much lower: 0.00 (all samples, except male cones of $P$. mugo, mature female cones of $P$. sylvestris, pollen of $P$. armandii) -3.70 (pollen of $P$. nigra) $\log \mathrm{cfu} / \mathrm{g}$. Samples of $P$. nigra and also $P$. armandii are the most contaminated by mesophilic bacteria among all the samples of pollen. In this group of microorganisms was not possible to identify bacteria using MALDITOF on a reliable level.

Enterococci were not detected on investigated Pinus samples. It's a good result from the sanitary point of view.

Unfortunately, total coliforms were found out on samples at the level from 0.00 (young and mature female cones, needles and pollen of $P$. sylvestris) to enough 
high - 5.29 (pollen of P. nigra) log cfu/g. Pollen is more contaminated by coliforms than male cones. Pantoea agglomerans was identified using MALDITOF within this group of microorganisms. This is the most common species on investigated Pinus samples. It was revealed on all pollen samples and male cones Also Klebsiella pneumonia was identified on male cones of $P$. sylvestris before and during flowering.

The amount of lactobacilli varies from 0.00 (male cones of $P$. nigra, pollen of $P$. nigra and $P$. armandii) to 4.20 (young female cones of $P$. sylvestris) $\log$ cfu/g. In general, lactobacilli are much observed on other parts of the tree rather than on pollen. During the analysis it was found that this group of microorganisms to identify the hardest. It was possible to identify only unusual to this group of microorganisms.

Colonies of microscopic fungi and yeasts are most numerical. They were detected in all the samples, without exception. The fewest of microscopic fungi and yeasts were defined on the needles of $P$. sylvestris $(2.60 \mathrm{log} \mathrm{cfu} / \mathrm{g})$, the greatest number - on the pollen P. wallichiana (5.29 $\mathrm{log} \mathrm{cfu} / \mathrm{g}$ ). During flowering the level of microscopic fungi and yeasts is higher on parts of the tree involved in flowering, meaning male cones and pollen. A number of yeast colonies in comparison with the colonies of microscopic fungi is more numerical. Representatives of the genera Penicillium, Aspergillus, Alternaria, Cladosporium, Rhodotorula and unidentified genus Mycelium sterillium without creation fruiting bodies were determined microscopically. Then presence of Penicillium chrysogenum, $P$. digitatum, $P$. italicum, $P$. roqueforti, $P$. expansum, $P$. commune, Cladosporium herbarum, Aspergillus oryzae, A. flavus, A. versicolor, A. parasiticus, among yeast - Debaryomyces hansenii was confirmed by MALDI-TOF. Also, the presence of such yeasts like Candida sorbosa, C. guilliermondii, C. dubliniensis, Lodderomyces elongisporus have been revealed, but at the level of less than 1.7.

Table 2 The microbial species composition isolated from the parts of Pinus trees

\begin{tabular}{|c|c|c|}
\hline № & Identified microorganism & Part of Pinus trees \\
\hline 1 & Pseudomonas asplenii & Pollen PS \\
\hline 2 & Pseudomonas chlororaphis & Pollen PS \\
\hline 3 & Pseudomonas corrugata & Pollen PS \\
\hline 4 & Pseudomonas koreensis & Pollen PS \\
\hline 5 & Pseudomonas orientalis & Pollen PN \\
\hline 6 & Pseudomonas tolaasii & Pollen PN, PS \\
\hline 7 & Pseudomonas rhodesiae & Pollen PN \\
\hline 8 & Pseudomonas fluorescens & Pollen PN \\
\hline 9 & Pseudomonas libanensis & Pollen PN \\
\hline 10 & Pseudomonas veronii & Pollen PN \\
\hline 11 & $\begin{array}{l}\text { Pseudomonas } \\
\text { extremorientalis }\end{array}$ & Pollen PN \\
\hline 12 & Pseudomonas trivialis & Pollen PN \\
\hline 13 & Pseudomonas synxantha & Pollen PN \\
\hline 14 & Pseudomonas grimontii & Pollen PN \\
\hline 15 & Bacillus flexus & Pollen PW \\
\hline 16 & Bacillus licheniformis & Pollen PS, PM, PW \\
\hline 17 & Acinetobacter lwoffii & Pollen PM, PS, PA \\
\hline 18 & Arthrobacter sp. & $\begin{array}{l}\text { Pollen PA } \\
\end{array}$ \\
\hline 19 & Pantoea agglomerans & $\begin{array}{l}\text { Pollen PS, PM, PW, PA, PN, male cones } \\
\text { PS, PM, PN DF, male cones PS AF }\end{array}$ \\
\hline 20 & Klebsiella pпеитопiа & Male cones PS BF and DF \\
\hline 21 & Penicillium chrysogenum & Pollen PS, PM \\
\hline 22 & Penicillium digitatum & Pollen PS, PM, PA \\
\hline 23 & Penicillium italicum & Pollen PS, PM \\
\hline 24 & Penicillium roqueforti & Pollen PM, PA, PS \\
\hline 25 & Penicillium expansum & Pollen PA, PS \\
\hline 26 & Penicillium commune & Pollen PA \\
\hline 27 & Cladosporium herbarum & Pollen PS, PN, PM, PA, PW \\
\hline 28 & Aspergillus oryzae & Pollen PA, PN, PW, PS \\
\hline 29 & Aspergillus flavus & Pollen PN, PW, PA, PS \\
\hline 30 & Aspergillus versicolor & Pollen PS \\
\hline 31 & Aspergillus parasiticus & Pollen PS, PN, PA \\
\hline 32 & Debaryomyces hansenii & $\begin{array}{l}\text { Pollen PS, PN, PM, PA, PW, male cones } \\
\text { PS DF, AF, mature female cones PS }\end{array}$ \\
\hline
\end{tabular}

$\mathrm{BF}$ - before flowering; $\mathrm{DF}$ - during flowering; $\mathrm{AF}$ - after flowering

As shown the microbiological and statistical analysis, samples of pine pollen are more contaminated by microorganisms than other parts of trees (see Table 2). There are no significant differences between the number of microorganism colonies of pollen and male cones during flowering period after paired comparison (see Figure 1). However, there was found a strong tendency to the predominance of anaerobic bacteria in the pollen, in comparison with the cones at the stage of flowering $(\mathrm{p}=0.07)$. It is also proved that the number of fungi and yeasts colonies on the male cones after flowering less than on pollen $(\mathrm{U}=4$, $\mathrm{p}=0.015$ ).

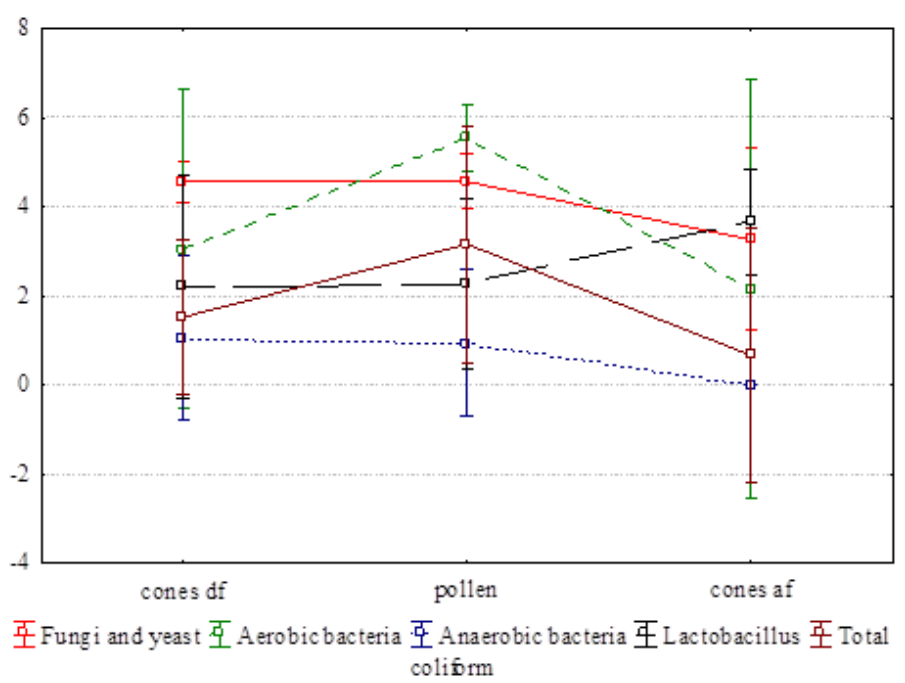

Figure 1 Comparison of the number of colonies of microorganisms groups on pollen and male cones of Pinus during and after flowering using Mann-Whitney U-test

Pollen of $P$. sylvestris has the most diverse composition of the microbiota. Of the 32 identified microorganisms 20 species of them belong to $P$. sylvestris samples, 15 to $P$. nigra, whereas 11 to $P$. armandii, 8 to $P$. mugo, only 6 to $P$. wallichiana Pantoea agglomerans, Debaryomyces hansenii and Cladosporium herbarum are microorganisms the most commonly found on Pinus samples.

Bacillus licheniformis, Pantoea agglomerans, Penicillium commune, $P$. verrucosum, $P$. roqueforti, $P$. italicum, $P$. digitatum, $P$. expansum, $P$. lanosum, $P$. corylophilum, Mucor ramosissimus, M. circinelloides, Chaetomium funicola, Rhizopus stolonifer, Absidia coerulea, Alternaria alternata, Aureobasidium pullulans, Paecilomyces lilacinus, Cladosporium sp., unidentified genus Mycelium sterillium without creation fruiting bodies were found in the air samples around the pines at the Botanical garden. The composition of the microbiota of the air is quite diverse. According to data of the aerobiological station of Nitra region of the Slovak Republic concentrations of fungal spores were at level "very high" in the days of sampling the air (more than 150 particles per $1 \mathrm{~m}^{3}$ of air). During the flowering season of Pinus only daily concentration of Cladosporium spores were at significant level in the Nitra region (values of average weekly concentrations of spores per $1 \mathrm{~m}^{3}$ of air were in the range 27 141). The Cladosporium spores generally exceed all other airborne biologic particles in outdoor air (Ozdemir, 2015). Concentration levels of Alternaria (1$\left.8 / \mathrm{m}^{3}\right)$, Epicoccum $\left(0-3 / \mathrm{m}^{3}\right)$, Stemphylium $\left(1-3 / \mathrm{m}^{3}\right)$, Helminthosporium $\left(0 / \mathrm{m}^{3}\right)$ spores in the air of Nitra region were low or very low. Allergic relevant concentrations of Pinus pollen in the air was not observed (www.alergia.sk).

\section{DISCUSSION}

Thus, it has been detected and partially identified representatives of mesophilic aerobic and anaerobic bacteria, lactobacilli, coliform bacteria, microscopic fungi and yeasts on samples of pollen, male and female cones, needles of five representatives of Pinus species, that grow at the Botanical garden in Nitra, Slovakia. Microscopic fungi and yeasts are the largest group of microorganisms for the Pinus trees (mean=4.28 log cfu/g) and aerobic bacteria $(4.00 \mathrm{log} \mathrm{cfu} / \mathrm{g})$ the least - anaerobes $(0.85 \mathrm{log} \mathrm{cfu} / \mathrm{g})$. Young female cones are the least contaminated by microorganisms among all investigated parts of the tree (identified only representatives of lactobacilli, microscopic fungi and yeast). It is quite logical: young female cones are just beginning to take shape after pollination. There are enough nutrients on other organs of the tree for the bacteria. The presence of microscopic fungi and spores can be explained by the fact that fungi are the most common organisms in nature (Latha and Mohan, 2013). Moreover, pollen is better partner in the air for the airborne microorganisms (Després et al., 2012; Sapiňa et al., 2013). Mature last year's female cones and needles are also less attractive to microorganisms in comparison with pollen and male cones. Representatives of only three groups of microorganisms from the six examined were identified on it. Perhaps, this is because of the flowering period. Pollen abundantly releases, pour out on all parts of the plant, it is in the air and bacteria cannot not dealing with it.

There are differences among Pinus species in the quantitative composition of the microbiota of the male cones in the flowering period. These differences are most appreciable in quantitative composition of aerobes, anaerobes and lactobacilli. There are also species differences in the level of pollen microbial contamination. Pollen of $P$. sylvestris contaminated least by all groups of microorganisms (on average $2.78 \mathrm{log} \mathrm{cfu} / \mathrm{g}$ ). Pollen of $P$. wallichiana contaminated most $(3.96 \mathrm{log}$ cfu/g). The result is interesting because although pollen of $P$. sylvestris less contaminated quantitatively, the qualitative composition of it microbiota is most diverse. In the case of $P$. wallichiana pollen the result is opposite (see Table 2). 
The level of contamination by all groups of microorganisms of $P$. nigra pollen is $3.79 \log \mathrm{cfu} / \mathrm{g}$, P. mugo $-3.44 \mathrm{log} \mathrm{cfu} / \mathrm{g}, P$. armandii $-3.22 \log \mathrm{cfu} / \mathrm{g}$. It was found the absence of representatives of microorganisms, at least, for two groups for all species of pollen.

With regard to the microbiota of $P$. sylvestris - species, for which the microbiological composition was done the most complete, quantitatively differences were revealed between the trees organs of this species. Thus, male cones most contaminated by coliform bacteria, fungi and yeast at different stages concerning the period of flowering, pollen - by aerobic bacteria, mature female cones - by anaerobic bacteria, young - by lactobacilli.

Quantitative microbiological analysis of Pinus trees and air samples near the trees showed that microscopic fungi, yeast, aerobic bacteria are the most widespread microorganisms during the flowering period of this genus. Their colonies are most often on the pollen and the male cones in the flowering period And after this period there is a tendency to reduce them on the male cones. This indicates that the reason for the presence of microorganisms is pollen. Since pollen samples were investigated before their release into the environment, it is possible to assume that pollen contamination by these representatives occurs before the mass flowering. Madmony et al. (2005) also consider that different fungi and bacteria are located inside the pollen cells probably before the opening of the catkins. Likely the pollen contamination is caused by airborne microbiota encountered during pollen collection and handling. Content of air microbiota may be the proof. With regard to species differences in composition of the microbiota of pollen, the clear tendency for representatives of taxonomically related species subgenus Pinus and subgenus Strobus have not been identified. The representatives of these subgenera flowered with a difference of one month Weather conditions were optimal. Maňka et al. (2013) presented results that show closeness of the pollen viability characteristics in taxonomically related species of pines growing on the same territory and shedding their pollen in the same period of time as compared with the comparing characteristics of pollen in taxonomically distant species shedding their pollen in different periods of the flowering time.

Based on the analysis of the quantitative composition of the microbiota of Pinus representatives can assume about an allergenic potential of pollen. Based on the analysis of qualitative composition the assumptions will be more thorough.

In general, 32 species of microorganisms belonging to the aerobic and coliform bacteria, fungi and yeasts were identified with MALDI-TOF. Their number is maybe even more diverse, but to confirm this on confidence level was not possible. Representatives of Pseudomonas (14 species), Penicillium (6 species) and Aspergillus (4 species) appeared the most various. In recent years, Pseudomonas strains have been studied with increasing interest due to their importance in medical, food and environmental microbiology and phytopathology (Baïda et al., 2002). Genus Pseudomonas has environmental interest. Plant growth promoters, plant pathogens and xenobiotic degraders are among them. It is also one of the most important and best-studied bacterial taxa in soil (Ivanova et al., 2002; Bultreys et al., 2003; Garbeva et al., 2004; Moore et al., 2006). Really, 9 from 14 representatives of Pseudomonas genus can be found in the soil (Brodey et al., 1991; Bodelier and Laanbroek, 1997; Behrendt et al., 2003; Kwon et al., 2003; Haas and Keel, 2003), other five were isolated from the aquatic ecosystems (Elomari $\boldsymbol{e t}$ al., 1996; Dabboussi $\boldsymbol{e}$ al., 1999; Baïda et al., 2002; Ivanova et al., 2002). Pseudomonas, as different epiphytes, may influence plant productivity negatively, e.g., through induction of frost injury, or positively, e.g., by production of phytohormones that improve development. Phytopathogenic Pseudomonas species are distributed worldwide causing diseases of most major groups of higher plants. They generally can be found only on diseased plants, in which they appear as relatively homogeneous populations when the pathological lesions are young (Moore et al., 2006).

From the natural airborne allergens, pollen of grass and trees are the most important outdoor allergenic sources. Other important allergenic sources are airborne mould (Benndorf $\boldsymbol{e t}$ al., 2008). The genera of molds causing allergy and allergy-related problems most often are Alternaria alternata, Cladosporium herbarium, Aspergillus fumigates and Penicillium (Ozdemir, 2015). Penicillium species are among the most common fungi present in the environment Observably, Penicillium is one of the most abundant fungal floras with the intention that there are $10^{6}-10^{8}$ spores in one gram of normal soil and $10^{4}$ spores in one milliliter of unpolluted groundwater. They are usually considered nonpathogenic to humans. Penicillium species can cause opportunistic infections (Oshikata et al., 2013). Aspergillus infections have grown in importance in the recent years (Hedayati et al., 2007). Several species of Aspergillus have been shown to be allergenic, including $A$. fumigatus, A. niger, A. flavus and A. oryzae. A. oryzae and A. flavus are the two species are so closely related. A. flavus is the second leading cause of invasive aspergillosis and it is the most common cause of superficial infection (Hedayati et al., 2007). Aflatoxins, produced predominantly by fungi such as A. flavus and A. parasiticus, are among the most potent natura carcinogens known (Yu et al., 2003). In humans there is cross-reactivity to Aspergillus and Penicillium: most sera from patients with precipitins against Penicillium have precipitins against Aspergillus (Oshikata et al., 2013).

Also interesting representatives of the microbiota of anemophilous pine pollen is Pantoea agglomerans, Pseudomonas libanensis, P. veronii, P. extremorientalis, P. grimontii (Špiewak et al., 1996; Baïda et al., 2002; Leclerc, 2003; Nam et al., 2003; Egamberdieva, 2011). P. agglomerans (formerly Enterobacter agglomerans) is phytopathogen causing human disease. Špiewak et al. (1996) showed that $P$. agglomerans is present on pollen grains as well as endotoxin - the bacterial product having strong immunomodulating properties. From the literature it is known that the abovementioned Pseudomonas were isolated from natural springs in Lebanon, Russia, France. Pseudomonas extremorientalis, $P$. chlororaphis and $P$. veronii have the ability to survive in ecologically stressed conditions, such as saline soils, contaminated soils with simple aromatic organic compounds (Nam et al., 2003; Egamberdieva, 2011).

We classified representatives of identified microorganisms as to their pathogenic properties based on published data. Thus, eight microorganisms belong to phytopathogens (Pseudomonas asplenii, P. corrugata, P. tolaasii, P. digitatum, $P$. italicum, $P$. expansum, $C$. herbarum, $P$. agglomerans), 4 species to human pathogen ( $P$. fluorescens, $K$. pneumonia, $P$. chrysogenum, $P$. commune), with possible pathogenic properties 6 microorganisms ( $P$. trivialis, A. lwoffii, A oryzae, A. flavus, A. versicolor, A. parasiticus), not pathogen -5 ( $P$. chlororaphis, B. licheniformis, Arthrobacter sp., P. roqueforti, D. hansenii), unknown pathogenicity -9 representatives of identified species $(P$. orientalis, $P$. koreensis, $P$. rhodesiae, $P$. libanensis, $P$. veronii, $P$. extremorientalis, $P$. synxantha, $P$. grimontii, B. flexus, ). So, according to literature data, $56 \%$ of the identified microorganisms in samples of Pinus representatives have pathogenic nature, $16 \%$ - not pathogenic and $28 \%$ - unknown. According to the «List of airborne pathogens, including allergenic, toxigenic, and suspected respiratory and non-respiratory pathogens») eight identified microorganisms (K. pneumonia, Acinetobacter, $P$. chrysogenum, $P$. commune, $P$. expansum, A. flavus, $A$. versicolor, $C$. herbarum) correspond to the list (Breitenbach and Simon-Nobbe, 2002; Schwab et al., 2004; Fomicheva et al., 2006; Hedayati et al., 2007; Debarry et al., 2010). Cases of allergic sensitization are known also for $A$. oryzae and D. hansenii (Barbesgaard et al., 1992; Yamamoto et al., 2002) Frequency of occurrence of allergenic species on pollen of $P$. sylvestris is 9 from 10, P. armandii -8 from 10, P. nigra, P. mugo and $P$. wallichiana -5 from 10 . That is, theoretically, all the investigated pollen samples of Pinus carry allergenic stimuli on themselves.

Also among the identified microorganisms are those that have useful properties For example, Pseudomonas chlororaphis (acting against various fungal plant pathogens by creating phenazine), Pseudomonas synxantha - a fluorescent rhizosphere bacterium with nematicidal properties, Bacillus licheniformis, that demonstrates antifungal activity by producing an antibiotic that acts against fungi, Penicillium roqueforti are used to produce compounds that can be employed as antibiotics, flavours and fragrances (Wechter $\boldsymbol{e t}$ al., 2002; Rij $\boldsymbol{e t}$ al. 2004; Pringle, 2005; Ropars et al., 2012). Among «bad» microorganisms there are representatives also with useful properties. For example, Aspergillus versicolor is very effective at removing lead ions, Aspergillus oryzae is used in rice saccharification for sake brewing (Kitamoto, 2002; Fomicheva et al., 2006) On the basis of microbiological analysis, and analysis of literature data, making a conclusion about the potential allergenicity of Pinus pollen it can be assumed that pollen of $P$. sylvestris would most allergenic. Most of microorganisms were identified on these samples (20 of 32), the frequency of occurrence of allergenic species is maximal -9 out of 10 , but in general, the pollen of $P$. sylvestris leas contaminated by microorganisms $(2.78 \log \mathrm{cfu} / \mathrm{g})$, the third highest level of contamination by aerobic bacteria $(5.66 \mathrm{log} \mathrm{cfu} / \mathrm{g})$, and the fourth - of contamination by fungi and yeasts $(4.32 \log \mathrm{cfu} / \mathrm{g})$. The percentage of occurrence of allergenic species of microorganisms among identified should be consider as more important factor. It is $45 \%$ for $P$. sylvestris pollen. According to the same criteria pollen of $P$. nigra possess the minimum allergenic potential $-33.3 \%$. This pollen sample is characterized by a variety of the presence of Pseudomonas. $P$. mugo $(62.5 \%)$ and $P$. armandii $(72.7 \%)$ have the average potential of allergenicity. Pollen of $P$. wallichiana has a minimum number of the identified microorganisms - only 6 out of 32 , but it is more contaminated with microorganisms (3.96 log $\mathrm{cfu} / \mathrm{g}$ ), has the maximum values of the presence of fungi and yeast (5.29 $\mathrm{log} \mathrm{cfu} / \mathrm{g})$, a second indicator of contamination by aerobic bacteria $(6.02 \mathrm{log} \mathrm{cfu} / \mathrm{g})$, and $83 \%$ of the identified species of microorganisms among the presented on the pollen grains of $P$. wallichiana have the allergenic properties.

As a conclusion, available microbiota on pine pollen or associated with pines can be an addition factor of allergic sensibilization of sensitive persons. The gained results may be useful for aerobiologists, allergists and microbiologists, at least at the local level.

\section{CONCLUSION}

Microbiota of anemophilous Pinus pollen has been analyzed to evaluate it allergenic potential. Microbiota of other plant organs of Pinus trees has been examined to compare it with pollen. The content of revealed microbiota is multifarious: absence of representatives of Enterococcus, minimum mesophilic anaerobic bacteria and maximum microscopic fungi, yeast and mesophilic aerobic bacteria. Among them Pseudomonas, Penicillium and Aspergillus are most widespread on pine pollen grains. Among 32 identified microorganisms $56 \%$ of them have pathogenic nature and $16 \%$ - not pathogenic. All the investigated Pinus pollen contact with potentially allergenic species of 
microorganisms, $P$. wallichiana mostly, $P$. nigra least of all. Based on literature data airborne Pinus pollen can be a contributing factor in development of respiratory allergy. For the development of the allergenic properties of pine pollen for sensitive person match a range of other environmental factors is necessary. For example, the mass distribution of the species, weather conditions, the negative impact of anthropogenic factors, etc.

Acknowledgments: Co-author T. Shevtsova is grateful to National Scholarship Programme of the Slovak Republic for providing a scholarship for the research internship, during which she received the results and knowledge presented in this paper. T. Shevtsova is also very grateful to Ing. J. Kačinová, PhD. for help in fungi identification. This work has been supported by the Excellence Center for Agrobiodiversity Conservation and Benefit (ECACB) project implemented under the Operational Programme Research and Development financed by European Fund for Regional Development, ITMS 26220120015.

\section{REFERENCES}

Alergia.sk. (2015). www.alergia.sk.

Baïda, N., Yazourh, A., Singer, E., Izard, D. (2002). Pseudomonas grimontii sp. nov. Int $J$ Syst Evol Microbiol., 52, 1497-1503. DOI: http://dx.doi.org/10.1099/00207713-52-5-1497

Barberis, C., Almuzara, M., Join-Lambert, O., Ramírez, M. S., Famiglietti, A., Vay, C. (2014). Comparison of the Bruker MALDI-TOF Mass Spectrometry system and conventional phenotypic methods for identification of Gram-Positive $\begin{array}{llll}\text { Rods. } & P L O S & \text { ONE, } & \text { 9(9): } 106303 .\end{array}$ http://dx.doi.org/10.1371/journal.pone.0106303

Barbesgaard, P., Heldt-Hansen, H. P., Diderichsen, B. (1992). On the safety of Aspergillus oryzae: a review. Applied Microbiology and Biotechnology, 36(5), 569-572. DOI: http://dx.doi.org/10.1007/bf00183230

Behrendt, U., Ulrich, A., Schumann, P. (2003). Fluorescent pseudomonads associated with the phyllosphere of grasses; Pseudomonas trivialis sp. nov. Pseudomonas poae sp. nov. and Pseudomonas congelans sp. nov. Int J Syst Evol Microbiol., 53, 1461-1469. DOI: http://dx.doi.org/10.1099/ijs.0.02567-0

Behrendt, H., \& Becker, W.-M. (2001). Localization, release and bioavailability of pollen allergens: the influence of environmental factors. Current Opinion in Immunology, 14(1), 709-715. DOI: http://dx.doi.org/10.1016/s09527915(01)00283-7

Benndorf, D., Müller, A., Bock, K., Manuwald, O., Herbarth, O., von Bergen, M. (2008). Identification of spore allergens from the indoor mould Aspergillus versicolor. Allergy, 63(4), 454-460. DOI: http://dx.doi.org/10.1111/j.13989995.2007.01603.x

Bodelier, P., Laanbroek, H. (1997). Oxygen uptake kinetics of Pseudomonas chlororaphis grown in glucose- or glutamate-limited continuous cultures. Research Microbiology, 167(6), 392-395. DOI http://dx.doi.org/10.1007/s002030050460

Breitenbach, M., \& Simon-Nobbe, B. (2002). The Allergens of Cladosporium herbarum and Alternaria alternate. Fungal Allergy and Pathogenicity. Chem Immunol. Base. Karger, 81, 48-72. DOI: http://dx.doi.org/10.1159/000058862

Brodey, C.L., Rainey, P.B., Tester, M., Johnstone, K. (1991). Bacterial blotch disease of the cultivated mushroom is caused by an ion channel forming lipodepsipeptide toxin. Molecular Plant-Microbe Interactions, 4, 407-411. DOI: http://dx.doi.org/10.1094/MPMI-4-407

Bultreys, A., Gheysen, I., Wathelet, B., Maraite, H., de Hoffmann, E. (2003) High-performance liquid chromatography analyses of pyoverdin siderophores differentiate among phytopathogenic fluorescent Pseudomonas species. Applied and Environmental Microbiology, 69(2). DOI http://dx.doi.org/10.1128/AEM.69.2.1143-1153.2003

Dabboussi, F., Hamze, M., Elomari, M., Verhille, S., Baida, N., Izard, D. Leclerc, H. (1999). Pseudomonas libanensis sp. nov., a new species isolated from Lebanese spring waters. Int $J$ Syst Bacteriol., 49, 1091-1101. DOI: http://dx.doi.org/10.1099/00207713-49-3-1091

D'Amato, G., Cecchi, L., Bonini, S. Nunes, C., Annesi-Maesano, I., Behrendt, H., Liccardi, G., Popov, T., van Cauwenberge, P. (2007). Allergenic pollen and pollen allergy in Europe. Allergy, 62(9), 976-990. DOI: http://dx.doi.org/10.1111/j.1398-9995.2007.01393.x

Debarry, J., Hanuszkiewicz, A., Stein, K., Holst, O., Heine, H. (2010). The allergy-protective properties of Acinetobacter lwoffii F78 are imparted by its $\begin{array}{lll}\text { lipopolysaccharide. } & \text { Allergy, 65(6), 60-697. DOI: }\end{array}$ http://dx.doi.org/10.1111/j.1398-9995.2009.02253.x

DeMarco, M. L., \& Burnham, C.-A. D. (2014). Diafiltration MALDI-TOF Mass Spectrometry method for culture-independent detection and identification of pathogens directly from urine specimens. Am J Clin Pathol., 141(2), 204-212. DOI: http://dx.doi.org/10.1309/AJCPQYW3B6JLKILC

Després, V. R., Huffman, J. A., Burrows, S. M., Hoose, C., Safatov, A. S., Buryak, G., Fröhlich-Nowoisky, J., Elbert, W., Andreae, M. O., Pöschl, U., Jaenicke, R. (2012). Primary biological aerosol particles in the atmosphere: a review. Tellus B, 64, 15598. DOI: http://dx.doi.org/10.3402/tellusb.v64i0.15598 Dušička, J., Mičieta, K., Brutovská, E., Samelova, A., Ščevkova, J., Zamečnikova, M., Terenova, A. (2013). Aeropalynological aspects in the detection of the quality of air in Bratislava. Ekológia (Bratislava), 32(1), 39-53. DOI: http://dx.doi.org/10.2478/eko-2013-0004

Dyakowska, J., \& Zurzycki, J. (1959). Gravimetric studies on pollen. Bull. l'Acad. Polon. Sci., 1(7), 11-17.

Egamberdieva, D. (2011). Survival of Pseudomonas extremorientalis TSAU20 and $P$. chlororaphis TSAU13 in the rhizosphere of common bean (Phaseolus vulgaris) under saline conditions. Plant Soil Environ., 57(3), 122-127.

Elomari, M., Coroler, L., Hoste, B., Gillis, M., Izard, D., Leclerc, H. (1996) DNA relatedness among Pseudomonas strains isolated from natural mineral waters and proposal of Pseudomonas veronii sp. nov. Int J Syst Bacteriol., 46 , 1138-1144. DOI: http://dx.doi.org/0.1099/00207713-46-4-1138

Fomicheva, G. M., Vasilenko, O. V., Marfenina, O. E. (2006). Comparative morphological, ecological, and molecular studies of Aspergillus versicolor (Vuill.) tiraboschi strains isolated from different ecotopes. Microbiology, 75(2), 186-191. DOI: http://dx.doi.org/10.1134/s0026261706020123

Garbeva, P., van Veen, J. A., van Elsas, J. D. (2004). Assessment of the diversity, and antagonism towards Rhizoctonia solani AG3, of Pseudomonas species in soil from different agricultural regimes. FEMS Microbiology Ecology, 47(1), 51-64. DOI: http://dx.doi.org/10.1016/s0168-6496(03)00234-4

Gastaminza, G., Lombardero, M., Bernaola, G., Antepara, I., Muňoz, D. Gamboa, P. M., Audicana, M. T., Marcos, C., Ansotegui, I. J. (2009) Allergenicity and cross-reactivity of pine pollen. Clinical \& Experimental Allergy, 39(9), 1438-1446. DOI: http://dx.doi.org/10.1111/j.13652222.2009.03308.x

González, G., Hinojo, M. J., Mateo, R., Medina, A., Jiménez M. (2005) Occurrence of mycotoxin producing fungi in bee pollen. International Journal of Food Microbiology, 105(1), 1-9. http://dx.doi.org/10.1016/j.ijfoodmicro.2005.05.001

Green, B. J., Yli-Panula, E., Dettmann, M., Rutherford, S., Simpson, R. (2003) Airborne Pinus pollen in the atmosphere of Brisbane, Australia and relationships with meteorological parameters. Aerobiologia, 19, 47-55.

Haas, D., Keel, C. (2003). Regulation of antibiotic production in root-colonizing Pseudomonas spp. and relevance for biological control of plant disease. Annual Reviews of Phytopathology, 41, 117-153. DOI: http://dx.doi.org/10.1146/annurev.phyto.41.052002.095656

Hedayati, M. T., Pasqualotto, A. C., Warn, P. A., Bowyer, P., Denning, D. W (2007). Aspergillus flavus: human pathogen, allergen and mycotoxin producer.
Microbiology,
153 ,
$1677-1692$
DOI

http://dx.doi.org/10.1099/mic.0.2007/007641-0

Heydenreich, B., Bellinghausen, I., König, B., Becker, W.-M., Grabbe, S., Petersen, A., Saloga, J. (2011). Gram-positive bacteria on grass pollen exhibit adjuvant activity inducing inflammatory $\mathrm{T}$ cell responses. Clinical \& Experimental Allergy, 42(1), 76-84. DOI: http://dx.doi.org/10.1111/j.13652222.2011.03888.x

Pine (Pinus). (2015). https://www.polleninfo.org.

Ivanova, E. P., Gorshkova, N. M., Sawabe, T., Hayashi, K., Kalinovskaya, N. I., Lysenko, A. M., Zhukova, N. V., Nicolau, D. V., Kuznetsova, T. A., Mikhailov, V. V., Christen, R. (2002). Pseudomonas extremorientalis sp. nov., isolated from a drinking water reservoir. Int J Syst Evol Microbiol., 52, 2113-2120. DOI http://dx.doi.org/10.1099/00207713-52-6-2113

Ivanová, H \& Bernadovičová, S. (2010). Species diversity of microscopic fung on Austrian pines growing in urban greenery of Nitra town. Folia Oecologica, 37(2), 168-180.

Kitamoto, K. (2002). Molecular Biology of the Koji Molds. Advances in Applied Microbiology, 51, 129-53. DOI: http://dx.doi.org/10.1016/S00652164(02)51004-2

Kormut'ák, A., Čamek, V., Čelková, M., Vooková, B., Maňka, P., Galgŏci, M., Boleček, P., Gömöry, D. (2013). Introgressive hybridization between Scots pine and mountain dwarf pine at two localities of northern Slovakia. Folia Ecologica 40(2), 201-205.

Kwon, S.W., Kim, J.S., Park, I. C., Yoon, S. H., Park, D. H., Lim, C. K., Go S. J (2003). Pseudomonas koreensis sp. nov., Pseudomonas umsongensis sp. nov. and Pseudomonas jinjuensis sp. nov., novel species from farm soils in Korea. Int J Syst Evol Microbiol., 53, 21-27. DOI: http://dx.doi.org/10.1099/ijs.0.02326-0 Latha, N., Mohan, M. R. (2013). Aeromycological study of Jnanabharathi campus, Bangalore University, Bangalore, Karnataka. Current Biotica, 7(1\&2), 83-87.

Leclerc, H. (2003). World Health Organization (WHO). Heterotrophic Plate Counts and Drinking-water Safety. In J. Bartram, J. Cotruvo, M. Exner, C Fricker, A. (Ed.), Relationships between common water bacteria and pathogens in drinking-water (pp. 80-118). London, UK: IWA Publishing.

Lee, K.-H., Kim, Ae-J., Choi, E.-Mi. (2009). Antioxidant and antiinflammatory activity of pine pollen extract in vitro. Phytother. Res., 23(1), 41-48. DOI http://dx.doi.org/10.1002/ptr.2525

Madmony, A., Chernin, L., Pleban, S., Peleg, E., Riov, J. (2005). Enterobacter cloacae, an obligatory endophyte of pollen grains of Mediterranean pines. Folia Microbiol., 50(3), 209-216. DOI: http://dx.doi.org/10.1007/bf02931568

Maňka, P., Galgóci, M., Kormut’ák, A., Čamek, V., Gömöry, D. (2013). Pollen quality in some representatives of the genus Pinus. Folia Oecologica, 40(1), 71 76. 
Mittag, D., Varese, N., Scholzen, A., Mansell, A., Barker, G., Rice, G., Rolland, J. M., O'Hehir, R. E. (2013). TLR ligands of ryegrass pollen microbial contaminants enhance Th1 and Th2 responses and decrease induction of Foxp3(hi) regulatory $\mathrm{T}$ cells. Eur. J. Immunol., 43(3), 723-733. DOI: http://dx.doi.org/10.1002/eji.201242747

Moore, E. R. B., Tindall, B. J., Martins dos Santos, V. A. P., Pieper, D. H., Ramos, J.-L., Palleroni, N. J. (2006). Nonmedical: Pseudomonas. Prokaryotes, 6, 646-703. DOI: http://dx.doi.org/10.1007/0-387-30746-X_21

Nam, I.-H., Chang, Y.-S., Hong, H.-B., Lee, Y.-E. (2003). A novel catabolic activity of Pseudomonas veronii in biotransformation of pentachlorophenol Applied Microbiology and Biotechnology, 62, 284-290. DOI: http://dx.doi.org/10.1007/s00253-003-1255-1

Noks, R. B. (1985). Biologija pyl'cy. Moskva: Agropromizdat.

Nôžková, J., Kačániová, M. \& Fatrcová-Šramková, K. (2014). Hodnotenie kvality obnôžkového pel'u. Nitra: Vydavatel'stvo SPU v Nitre.

Oshikata, C., Tsurikisawa, N., Saito, A., Watanabe, M., Kamata, Y., Tanaka, M. Tsuburai, T., Mitomi, H., Takatori, K., Yasueda, H., Akiyama, K. (2013). Fatal pneumonia caused by Penicillium digitatum: a case report. BMC Pulmonary Medicine, 13. DOI: http://dx.doi.org/10.1186/1471-2466-13-16

Oszlányi, J. (1997). Forest Health and Environmental Pollution in Slovakia. Environmental Pollution, 98(3), 389-392. DOI: http://dx.doi.org/10.1016/s02697491(97)00155-3

Ozdemir, O. (2015). Molds and Respiratory Allergy - Part 1. MOJ Immunol, 2(2). DOI: http://dx.doi.org/10.15406/moji.2015.02.00045

Özler, H., Pehlivan, S., Bayrak, F. (2009). Analysis of free amino acid and total protein content in pollen of some allergenic taxa. Asian Journal of Plant Sciences, 8(4), 308-312. DOI: http://dx.doi.org/10.3923/ajps.2009.308.312

Pringle, E. $\quad$ (2005). Bacillus lichenformis. http://web.mst.edu/ microbio/BIO221_2005/B_lichenformis.htm.

Rij, E. T., Wesselink, M., Chin-A-Woeng, T. F., Bloemberg, G. V., Lugtenberg, B. J. (2004). Influence of environmental conditions on the production of phenazine-1-carboxamide by Pseudomonas chlororaphis PCL1391. Molecular Plant-Microbe Interactions, 17(5), 557-566. DOI: http://dx.doi.org/10.1094/mpmi.2004.17.5.557

Ropars, J., Dupont, J., Fontanillas, Rodríguez de la Vega, R. C., Malagnac, F., Coton, M., Giraud, T., López-Villavicencio, E. M. (2012). Sex in cheese: evidence for sexuality in the fungus Penicillium roqueforti. PLOS one, 7(11), e49665. DOI: http://dx.doi.org/10.1371/journal.pone.0049665

Sapiňa, M., Jimenez-Relinque, E., Castellote, M. (2013). Controlling the levels of airborne pollen: can heterogeneous photocatalysis help. Environ. Sci. Technol., 47(20), 11711-11716. DOI: http://dx.doi.org/10.1021/es402467x

Schwab, C. J., Cooley, J. D., Jumper, C. J., Graham, S. C., Straus, D. C. (2004) Allergic inflammation induced by a Penicillium chrysogenum conidia-associated allergen extract in a murine model. Allergy, 59(7), 758-765. DOI http://dx.doi.org/10.1111/j.1398-9995.2004.00481.x

Shah, R., \& Grammer, L. C. (2012). An overview of allergens. Allergy Asthma Proc., 1(3), S2-5. DOI: http://dx.doi.org/10.2500/aap.2012.33.3531

Solntseva, M. P., \& Glazunova, K. P. (2010). Influence of industrial and traffic pollution on reproduction of spermatophytes. Journal of General Biology, 71(2), 163-175.

Śpiewak, R., Krysińska-Traczyk, E., Sitkowska, J., Dutkiewicz, J. (1996) Microflora of allergenic pollens - a preliminary study. Annals of Agricultural and Environmental Medicine, 3, 127-130.

Tóth, E. M., Borsodi, A. K., Felföldi, T., et al. (2013). Practical Microbiology: based on the Hungarian practical notes entitled "Mikrobiológiai Laboratóriumi Gyakorlatok". Budapest: Eötvös Loránd University.

Turos, O. I., Kovtunenko, I. N., Petrosian, A. A. (2013). Assessment of human exposure as a safety criterion of effect the ambient pollen aeroallergens. Gigijena naselenyh misc', 62, 42-46.

Vinhas, R., Cortes, L., Cardoso, I., Mendes, V.M., Manadas, B., Todo-Bom, A. Pires, E., Veríssimo, P. (2011). Pollen proteases compromise the airway epithelial barrier through degradation of transmembrane adhesion proteins and lung bioactive peptides. Allergy, 66(8), 1088-1098. DOI http://dx.doi.org/10.1111/j.1398-9995.2011.02598.x

Wechter, W. P., Begum, D., Presting, G., Kim, J. J., Wing, R. A., Kluepfel, D. A (2002). Physical mapping, BAC-end sequence analysis, and marker tagging of the soilborne nematicidal bacterium, Pseudomonas synxantha BG33R. OMICS, 6(1), 11-21. DOI: http://dx.doi.org/10.1089/15362310252780807

Yamamoto, Y., Osanai, S., Fujiuchi, S., Yamazaki, K., Nakano, H., Ohsaki, Y., Kikuchi, K. (2002). Extrinsic allergic alveolitis induced by the yeast Debaryomyces hansenii. Eur Respir J., 20(5), 1351-1353. DOI: http://dx.doi.org/10.1183/09031936.02.00030402

Yu, J., Mohawed, S. M., Bhatnagar, D., Cleveland, T. E. (2003). Substrateinduced lipase gene expression and aflatoxin production in Aspergillus parasiticus and Aspergillus flavus. Journal of Applied Microbiology, 95(6), 1334-1342. DOI: http://dx.doi.org/10.1046/j.1365-2672.2003.02096.x 